\title{
A Multifactorial Mechanism in the Superior Antimalarial Activity of $\alpha$-C-GalCer
}

\author{
John Schmieg, ${ }^{1,2}$ Guangli Yang, ${ }^{3,4}$ Richard W. Franck, ${ }^{3}$ and Moriya Tsuji ${ }^{1,5}$ \\ ${ }^{1}$ Department of Medical Parasitology, New York University School of Medicine, New York, NY 10010, USA \\ ${ }^{2}$ Department of Pathology, Johns Hopkins Hospital, Baltimore, MD 21287, USA \\ ${ }^{3}$ Department of Chemistry, Hunter College, New York, NY 10021, USA \\ ${ }^{4}$ Molecular Pharmacology and Chemistry Program, Memorial Sloan-Kettering Cancer Institute, New York, NY 10065, USA \\ ${ }^{5}$ HIV and Malaria Vaccine Program, Aaron Diamond AIDS Research Center, New York, NY 10016, USA
}

Correspondence should be addressed to Moriya Tsuji, mtsuji@adarc.org

Received 28 August 2009; Accepted 4 October 2009

Academic Editor: Abhay R. Satoskar

Copyright ( 2010 John Schmieg et al. This is an open access article distributed under the Creative Commons Attribution License, which permits unrestricted use, distribution, and reproduction in any medium, provided the original work is properly cited.

\begin{abstract}
We have previously shown that the C-glycoside analog of $\alpha$-galactosylceramide ( $\alpha$-GalCer), $\alpha$-C-GalCer, displays a superior inhibitory activity against the liver stages of the rodent malaria parasite Plasmodium yoelii than its parental glycolipid, $\alpha$-GalCer. In this study, we demonstrate that NK cells, as well as IL-12, are a key contributor for the superior activity displayed by $\alpha$-C-GalCer. Surprisingly, the diminished production of Th2 cytokines, including IL-4, by $\alpha$-C-GalCer has no affect on its superior therapeutic activity relative to $\alpha$-GalCer. Finally, we show that the in vivo administration of $\alpha$-C-GalCer induces prolonged maturation of dendritic cells (DCs), as well as an enhanced proliferative response of mouse invariant V $\alpha 14$ (V $\alpha 14 \mathrm{i})$ NKT cells, both of which may also contribute to some degree to the superior activity of $\alpha$-C-GalCer in vivo.
\end{abstract}

\section{Introduction}

Malaria remains one of the most serious and prevalent infectious diseases in the world. Approximately 500 million people acquire the disease annually, which leads to 2-3 million deaths per year. Malaria is caused by species of Plasmodium, an apicomplexan parasite transmitted in nature by mosquito vectors of the genus Anopheles. The life cycle of Plasmodium is the same no matter what the species, consisting of both sexual stages that occur in the mosquito vector and asexual stages that occur in a vertebrate host. The asexual stages can be divided into the pre-erythrocytic stages, which consist primarily of developmental events occurring within infected hepatocytes (the so-called liver stages), and the erythrocytic, or blood, stages, which occur in red blood cells, and which result in the signs and symptoms of malaria [1].

Numerous studies have shown that $\mathrm{T}$ cells, including $\mathrm{CD} 8+\mathrm{T}$ cells, CD4+T cells, $\gamma \delta$-T cells, and natural killer (NKT) cells play a key role in the immune response to the pre-erythrocytic stages of Plasmodium [2]. Of recent interest is the role of NKT cells, a unique population of lymphocytes that coexpress markers of NK cells along with a semi-invariant TCR. In mice, the TCR of most NKT cells consists of an invariant $\mathrm{V} \alpha 14 \mathrm{~J} \alpha 18 \alpha$ chain paired with a variable set of $\beta$ chains consisting primarily of $\mathrm{V} \beta 8.2, \mathrm{~V} \beta 7$, or $\mathrm{V} \beta 2$. This invariant $\mathrm{V} \alpha 14$ TCR (V $\alpha 14 \mathrm{i})$ enables NKT cells to recognize the MHC class I-like molecule CD1d, which is capable of presenting hydrophobic molecules such as lipids and hydrophobic peptides to V $\alpha 14$ i NKT cells $[3,4]$.

To date, only a few compounds have been shown to bind CD1d and stimulate V $\alpha 14 \mathrm{i}$ NKT cells. Of these, the prototype molecule is $\alpha$-galactosylceramide ( $\alpha$-GalCer), a glycolipid originally derived from a marine sponge extract. Previously, using a murine malaria model, we showed that $\alpha$-GalCer is able to directly mediate protection to the pre-erythrocytic stages of malaria in a manner dependent on $i \mathrm{NKT}$ cells, CD1d, and IFN- $\gamma$ [5]. More recently, we demonstrated that a structurally similar C-glycoside analog of $\alpha$-GalCer, $\alpha$-C-galactosylceramide ( $\alpha$-C-GalCer), is also capable of mediating protection to the pre-erythrocytic stages of malaria in a manner dependent on V $\alpha 14 \mathrm{i}$ NKT 

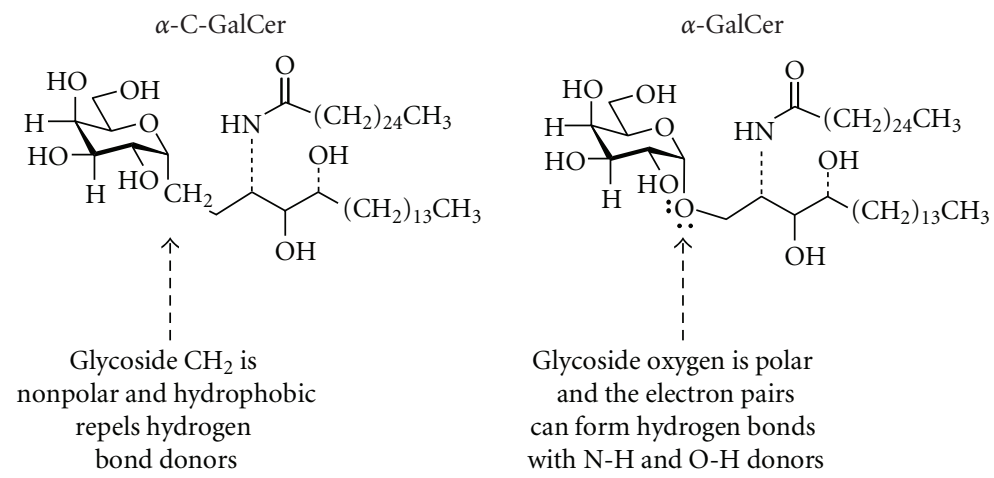

FIGURE 1: Structural comparison between $\alpha$-C-GalCer and $\alpha$-GalCer showing the main differences between the two molecules. Glycoside $\mathrm{CH}_{2}$ is nonpolar and hydrophobic; it repels hydrogen bond donors. In contrast, glycoside oxygen is polar, and the electron pairs can form hydrogen bonds with $\mathrm{N}-\mathrm{H}$ or $\mathrm{O}-\mathrm{H}$ donors.

cells, CD1d, and IFN- $\gamma$ [6]. Moreover, we showed that $\alpha$-CGalCer, which differs from $\alpha$-GalCer only in the identity of the chemical group involved in the glycosidic linkage of the galactose and ceramide moieties of the molecule (Figure 1), exhibits a much more potent and longer lasting antimalarial effect than $\alpha$-GalCer, an effect which appears to stem from prolonged downstream IFN- $\gamma$ production by NK cells, and which requires the presence of IL-12 [6]. In a follow-up study, we showed that CD $8 \alpha+$ dendritic cells (DCs) are the cells responsible for producing this IL-12 in response to glycolipid injection, and that depletion of these cells results in attenuated downstream IFN- $\gamma$ production by NK cells [7]. Our findings were corroborated by a more recent study by Fujii et al., which demonstrated that $\alpha$-C-GalCer induces higher degree of DC activation than $\alpha$-GalCer [8] .

In the present study, we further examine the physiologic mechanism underlying the superior antimalarial activity of $\alpha$-C-GalCer. We find that the mechanism involves IL-12, NK cells and DCs, but not the Th2 cytokines IL-4 and IL-10, nor the TCR $\beta$ used by the V $\alpha 14$ i NKT cells.

\section{Materials and Methods}

2.1. Chemicals. $\alpha$-galactosylceramide $\left[\left(2^{\prime} \mathrm{S}, 3^{\prime} \mathrm{S}, 4^{\prime} \mathrm{R}\right)-1^{\prime}-\mathrm{O}-(\alpha-\right.$ D-galactopyranosyl)-2-(N-hexacosanoylamino)-1,3,4-octadecanetriol] was synthesized by Kirin Brewery (Gumma, Japan). The stock solution was dissolved in a $0.5 \%$ polysorbate-20 (Nikko Chemical, Tokyo), $0.9 \% \mathrm{NaCl}$ solution at a concentration of $200 \mu \mathrm{g} / \mathrm{mL}$, and diluted in PBS to the desired concentration just prior to injection into mice.

$\alpha$-C-galactosylceramide [ $\left(2^{\prime} \mathrm{S}, 3^{\prime} \mathrm{S}, 4^{\prime} \mathrm{R}\right)-1^{\prime}-\mathrm{CH}_{2}-(\alpha$-D -galactopyranosyl)-2-(N-hexacosanoylamino)-3,4-nonadecanediol] was synthesized as described previously [9]. The stock solution, originally dissolved to a concentration of $1 \mathrm{mg} / \mathrm{mL}$ in $100 \%$ DMSO, was diluted to a working concentration of $200 \mu \mathrm{g} / \mathrm{mL}$ in a $0.5 \%$ polysorbate-20 (Nikko Chemical, Tokyo), $0.9 \% \mathrm{NaCl}$ solution. Before injection into mice, the working solution was further diluted to the desired concentration in PBS.

2.2. Mice. Six- to eight-week-old female BALB/c and C57BL/ 6 mice were purchased from the National Cancer Institute
(Bethesda, MD). IL-12p40-deficient mice of BALB/c and C57BL/6 backgrounds, IL-4-deficient mice of BALB/c background, and IL-10-deficient mice of C57BL/6 background were all purchased from the Jackson Laboratory (Bar Harbor, $\mathrm{ME})$.

2.3. Injections. For glycolipid treatments, mice were injected intraperperitoneally with $1 \mu \mathrm{g}$ of either $\alpha$-GalCer or $\alpha$-CGalCer. In some experiments, treated and untreated mice were challenged with live $P$. yoelii sporozoites 3 days later.

2.4. Parasites and Their Use for Challenge. P. yoelii (17XNL strain) was maintained by alternate cyclic passages in Anopheles stephensi mosquitoes and Swiss Webster mice. Sporozoites obtained from dissected salivary glands of infected mosquitoes 2 weeks after their infective blood meal were used for challenge of the mice. Challenge of mice to determine the development of liver-stage malaria infection was performed by an intravenous injection of 10,000 viable sporozoites into the tail vein. The outcome of the challenge was determined $40-42$ hours later by measuring the parasite burden in the livers of the mice using a quantitative real-time RT-PCR method [10].

2.5. Culture Medium. DMEM media supplemented with $10 \%$ heat-inactivated fetal calf serum (FCS) (DMEM10) and RPMI 1640 media supplemented with $10 \%$ heat-inactivated FCS (RPMI-10) were used in all experiments involving cell suspensions. In addition to FCS, the media were supplemented with $100 \mathrm{IU} / \mathrm{mL}$ of penicillin/streptomycin, $10 \mu \mathrm{g} / \mathrm{mL}$ of gentamicin, $10 \mathrm{mM}$ HEPES buffer, $50 \mu \mathrm{M}$ of $\beta$-mercaptoethanol, $2 \mathrm{mM}$ of L-glutamine, $1 \mathrm{mM}$ of sodium pyruvate, and $100 \mu \mathrm{M}$ of nonessential amino acids. All reagents were obtained from GIBCO (Carlsbad, CA) except FCS, which was obtained from HyClone (Logan, UT).

2.6. Determination of Malaria Liver Stage Development. The degree of liver stage development in challenged mice was determined by quantifying the amount of $P$. yoelii-specific $18 \mathrm{~S}$ ribosomal RNA (rRNA) molecules in the livers of the 
mice by way of a recently developed real-time RT-PCR technique [10]. 40-42 hours after sporozoite challenge, livers from challenged mice were dissected and homogenized in $4 \mathrm{~mL} /$ liver of denaturing solution $(4 \mathrm{M}$ guanidium thiocyanate, $25 \mathrm{mM}$ sodium citrate $\mathrm{pH} 7.0,0.5 \%$ sarcosyl, $0.1 \mathrm{M}$ $\beta$-mercaptoethanol) using a PowerGen 125 biohomogenizer (Fisher, Pittsburgh, PA). RNA was then purified from $600 \mu \mathrm{L}$ aliquots of the homogenates using the method developed by Chomczynski and Sacchi [11]. $2 \mu \mathrm{g}$ samples of the RNA were then reverse-transcribed, and aliquots of the resulting complementary DNA (cDNA) (133 ng) were used for real-time PCR amplification of $P$. yoelii 18S rRNA sequences. This amplification was performed in a GeneAmp 5700 Sequence Detection System (PE Applied Biosystems, Foster City, CA). For this purpose, we used primers $5^{\prime}$-GGGGATTGGTTTTGACGTTTTTGCG-3' (54 nM) and $5^{\prime}$-AAGCATTAAATAAAGCGAATACATCCTTAT-3' (60 nM) together with the double-stranded DNA (dsDNA)-specific dye SYBR Green I incorporated into the PCR reaction buffer (PE Biosystems, Foster City, CA) in order to detect the PCR product generated. The temperature profile of the reaction was $95^{\circ} \mathrm{C}$ for 10 minutes followed by 40 cycles of denaturation at $95^{\circ} \mathrm{C}$ for 15 seconds and annealing/extension at $60^{\circ} \mathrm{C}$ for 1 minute.

2.7. Isolation of Splenocytes and Intrahepatic Lymphocytes from Mice. Mouse splenocytes were prepared by gently grinding spleens between the frosted ends of two microscope slides in a petri dish containing $10 \mathrm{~mL}$ of DMEM-10 or RPMI-10 medium. The resulting cell suspension was filtered through nylon mesh, pelleted, and incubated with $5 \mathrm{~mL}$ of ACK lysis buffer for 5 minutes at room temperature to remove red blood cells. The cells were then washed three times with DMEM-10 or RPMI-10 medium, filtered once more through nylon mesh, and counted using a hemocytometer and tryphan blue (GIBCO, Carlsbad, CA).

Intrahepatic lymphocytes from mice were prepared by grinding livers in a steel mesh screen using a $3 \mathrm{~mL}$ syringe pestle, and filtering the resulting homogenate into a $50 \mathrm{~mL}$ tube using $45 \mathrm{~mL}$ of Hank's Balanced Salt Solution (HBSS) (GIBCO, Carlsbad, CA). After centrifugation of the homogenate, the pellet was resuspended in $45 \mathrm{~mL}$ of a $35 \%$ Percoll (Amersham Biosciences, Piscataway, NJ) solution (29.1 mL HBSS, $14.2 \mathrm{~mL}$ Percoll, $1.6 \mathrm{~mL}$ 10X PBS, $200 \mathrm{U}$ heparin), and centrifuged at $500 \mathrm{~g}$ for 10 minutes at 20 degrees Celsius. The resulting high-density liver lymphocyte pellet was resuspended in $5 \mathrm{~mL}$ of ACK lysis buffer for 5 minutes at room temperature to remove red blood cells, and then washed three times with DMEM-10 or RPMI10 medium. After the final wash, the cells were filtered through nylon mesh, and counted using a hemocytometer and tryphan blue.

2.8. Flow Cytometry Experiments. In order to measure the degree of DC maturation induced by $\alpha$-GalCer and $\alpha$-CGalCer, freshly isolated splenocytes from $\mathrm{BALB} / \mathrm{c}$ mice were first incubated for 15 minutes at $4^{\circ} \mathrm{C}$ with unlabeled antimouse Fc $\gamma$ III/II receptor mAb clone, 2.4G2 (PharMingen, San Diego, CA) in staining buffer (PBS containing $1 \%$
FBS and $0.1 \% \mathrm{NaN}_{3}$ ) to block Fc receptors. Next, the cells were surface stained with $\mathrm{PE}$-conjugated anti-CD11c $\mathrm{mAb}$ clone, HL3, and FITC-conjugated anti-CD86 mAb clone, GL1, FITC-conjugated anti-CD40 mAb clone, HM40-3, or syngeneic MHC-class II-specific FITC-conjugated anti-IA ${ }^{\mathrm{d}}$ mAb clone, AMS-32.1 (all PharMingen, San Diego, CA) in staining buffer for 30 minutes at $4^{\circ} \mathrm{C}$. After two washes in staining buffer, the cells were then analyzed using a FACSCalibur instrument (Becton Dickson, San Diego, CA) with CELLQuest software (Becton Dickson, San Diego, CA).

Next, in order to specifically detect V $\alpha 14$ i NKT cells, we first loaded mouse $\mathrm{CD} 1 \mathrm{~d}-\mathrm{IgG}_{1}$ dimer $\mathrm{X}$ molecules (PharMingen, Sand Diego, CA) with a 10-20-fold molar excess of $\alpha$-GalCer overnight in 1X PBS at room temperature. After preparation of splenocytes and liver lymphocytes, we incubated the cells with the loaded dimers for 60 minutes in staining buffer at 4 degrees Celsius (after Fc receptor block), using $4 \mu \mathrm{g}$ of loaded dimer for every $1 \times 10^{6}$ cells stained. Next, after washing the cells once with staining buffer, we surface stained the cells with FITC-labeled anti-CD3e mAb clone, $145-2 \mathrm{C} 11$, and PE-labeled antimouse $\mathrm{IgG}_{1}$ clone, A851 (both PharMingen, San Diego, CA) for 30 minutes in staining buffer at 4 degrees Celsius. Finally, after washing the stained cells twice with staining buffer, we analyzed them by FACS as detailed above.

Finally, in order to measure the TCR $\beta$ usage of $\mathrm{V} \alpha 14 \mathrm{i}$ NKT cells before and after in vivo $\alpha$-GalCer or $\alpha$-C-GalCer stimulation, we first incubated splenocytes and liver lymphocytes with unlabeled antimouse Fc $\gamma$ III/II receptor $\mathrm{mAb}$ clone, 2.4G2 (PharMingen, San Diego, CA) and unlabeled streptavidin (Molecular Probes, Eugene, OR) for 15 minutes in staining buffer at 4 degrees Celsius in order to block Fc receptors and surface biotin molecules. After washing the cells twice with staining buffer, we incubated the cells with $\alpha$ GalCer-loaded dimers in the manner indicated above. After dimer incubation, we surface stained the cells with FITClabeled anti-CD3e mAb clone, 145-2C11, and either biotinlabeled anti-V $\beta 8.1 / 8.2$ clone, MR5-2, biotin-labeled anti$\mathrm{V} \beta 7$ clone, TR310, or biotin-labeled anti-V $\beta 2$, clone B20.6 (all PharMingen, San Diego, CA) for 30 minutes in staining buffer at 4 degrees Celsius, followed by two washes with staining buffer. We then stained the cells with PE-labeled antimouse IgG $_{1}$ clone A85-1 and APC-labeled streptavidin (both from PharMingen, San Diego, CA) for 30 minutes in staining buffer at 4 degrees Celsius. Finally, after washing the cells twice with staining buffer, we analyzed them by FACS as detailed above.

\section{Results}

3.1. IL-12 Is a Key Factor in the Antimalarial Activity of Both $\alpha$-C-GalCer and $\alpha$-GalCer. In a previous study, we showed that $\alpha$-C-GalCer's ability to stimulate prolonged IFN- $\gamma$ production is abrogated in the absence of IL-12 [6]. Since IFN- $\gamma$ is required for $\alpha$-C-GalCer's anti-malaria effect, we wanted to see if its superior therapeutic activity against malaria liver stages was abrogated in the absence of IL-12 as well. To address this issue, we first treated both WT and IL12-deficient mice with equal doses of either glycolipid three 


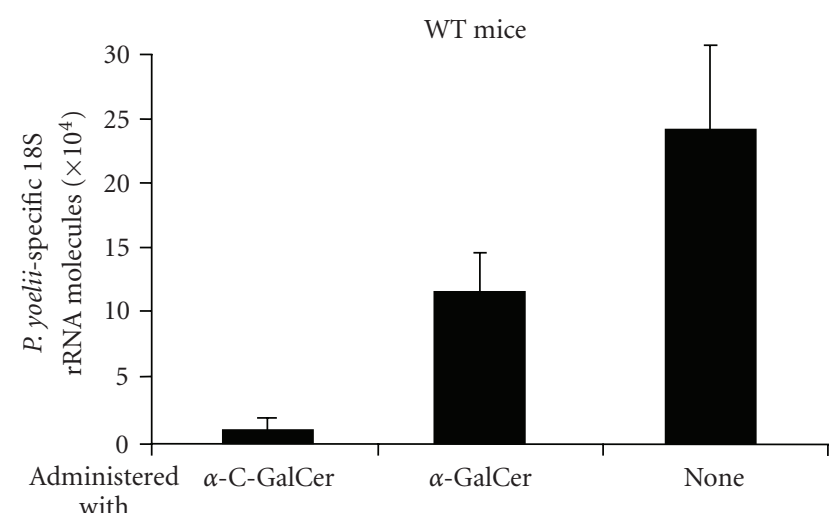

(a)

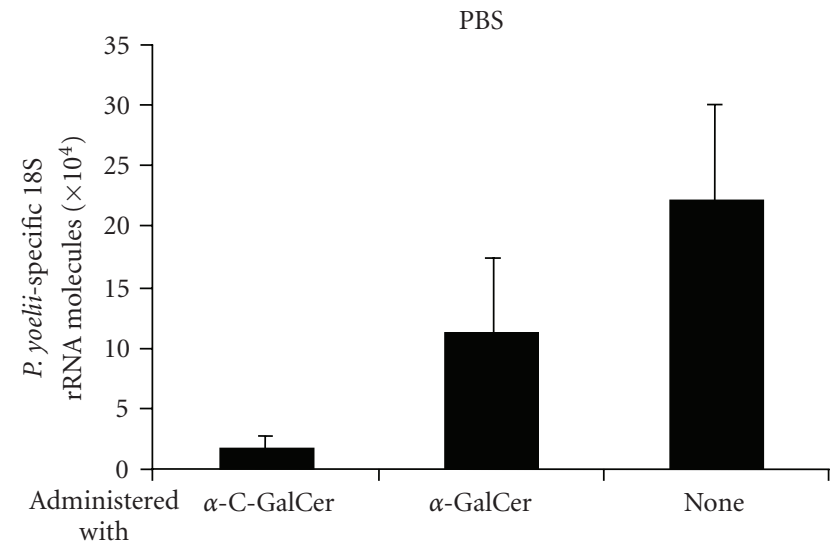

(c)

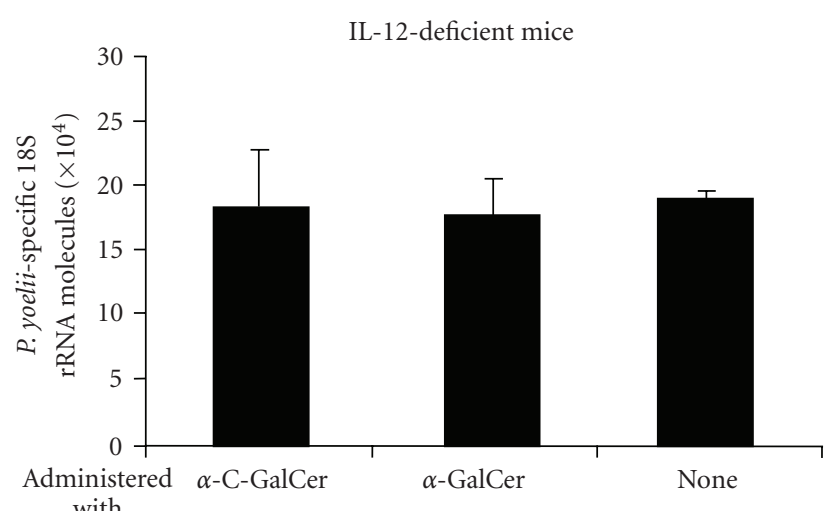

(b)

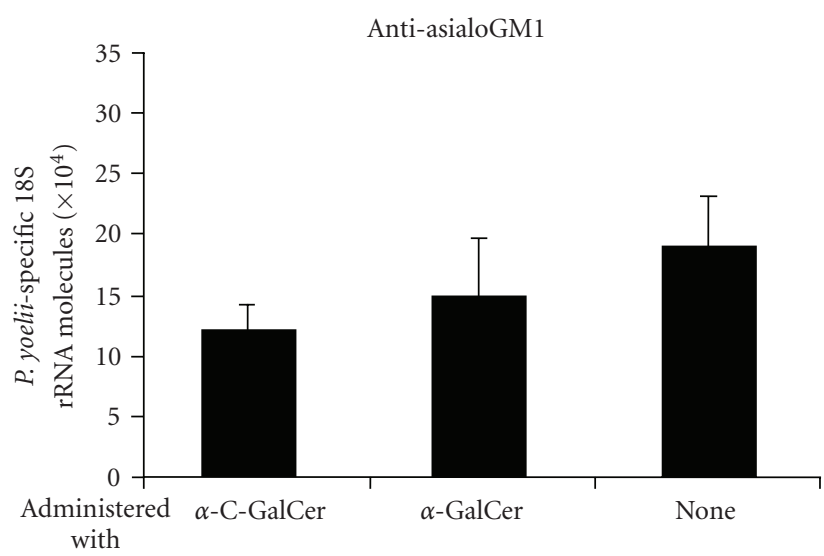

(d)

FIGURE 2: $\alpha$-C-GalCer's superior therapeutic activity against malaria liver stages requires IL-12 and NK cells. (a) Groups of 5 WT or IL12-deficient BALB/c mice were treated intraperitoneally (i.p.) with $1 \mu \mathrm{g}$ of either $\alpha$-C-GalCer or $\alpha$-GalCer or with nothing 3 days before challenge intravenously with live P. yoelii sporozoites, and then checked for malaria liver stage development. The results are expressed as the average +/- SD of 5 mice. (b) Groups of 5 WT C57BL/6 mice were treated i.p. with PBS or anti-asialoGM1 antibody 1 day prior to i.p. injection with $1 \mu \mathrm{g}$ of $\alpha$-C-GalCer or $\alpha$-GalCer, or with nothing. Three days later the mice were challenged with live $P$. yoelii sporozoites, and then checked for malaria liver stage development. The results are expressed as the average +/- SD of 5 mice. The data shown come from one of three experiments with similar results.

days before challenge with sporozoites, and then measured malaria liver stage development. As expected, in WT mice $\alpha$-C-GalCer suppressed liver stage development to a much greater degree than $\alpha$-GalCer; however, in IL-12-deficient mice the anti-malaria activity of both glycolipids was totally abolished (Figure 2(a)). Thus, IL-12 is a key factor not only driving $\alpha$-C-GalCer's superior antimalarial effect, but also mediating the antiplasmodial effect of both glycolipids.

\section{2. $\alpha$-C-GalCer's Enhanced Antimalarial Response Requires} the Presence of NK Cells. Our finding that $\alpha$-C-GalCer's superior antimalarial activity requires IL-12 (Figure 2(a)), which is required for optimal IFN- $\gamma$ production by NK cells following glycolipid administration [6], strongly suggests that NK cells are also required for $\alpha$-C-GalCer's superior antimalarial activity. To assess the role of NK cells in $\alpha$-GalCer- and $\alpha$-C-GalCer-mediated protection against malaria, we pretreated mice with anti-asiaoloGM1 antibody, which is known to selectively deplete NK cells [12], or with PBS, and one day later treated the mice with equal doses of $\alpha$-GalCer or $\alpha$-C-GalCer, or with nothing. Three days after glycolipid treatment, we challenged the mice with sporozoites and then measured liver stage development as before. We found that in nondepleted PBS-treated control mice, $\alpha$-C-GalCer exhibited better antimalarial activity than did $\alpha$-GalCer, as expected. In contrast, we observed an abrogation of $\alpha$-C-GalCer's superior antimalarial activity in mice depleted of NK cells with anti-asialoGM1 antibody (Figure 2(b)). This result strongly suggests that $\alpha$-C-GalCer's superior antimalarial effect stems from its ability to stimulate enhanced IL-12 production, which then triggers NK cells to produce more IFN $-\gamma$ needed to suppress malarial liver stage development.

3.3. $\alpha$-C-GalCer's Enhanced Antimalarial Response Does Not Involve the Th2 Cytokines IL-4 and IL-10. In an earlier study, we and others showed that mice injected with $\alpha$-C-GalCer produce a far less IL-4 than did those injected with $\alpha$ GalCer $[6,8]$. Given that IL-4 is a Th2 cytokine with known inhibitory activity against Th1 cytokines [13], we were 


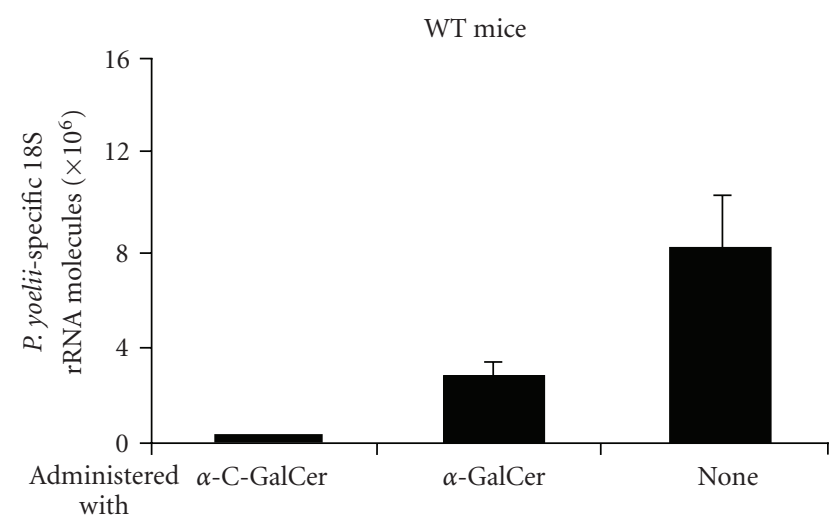

(a)

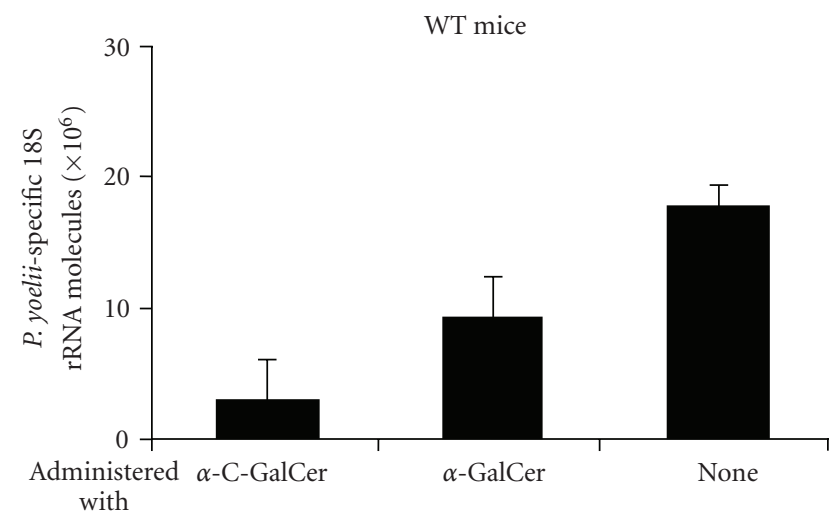

(c)

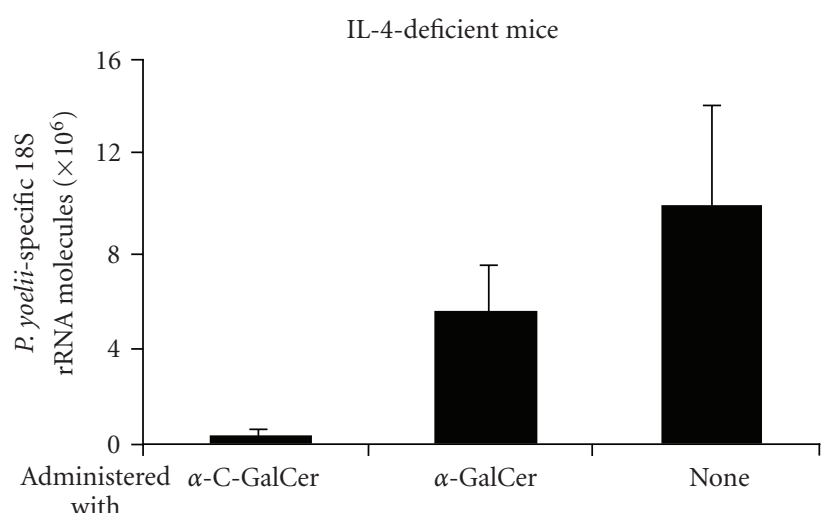

(b)

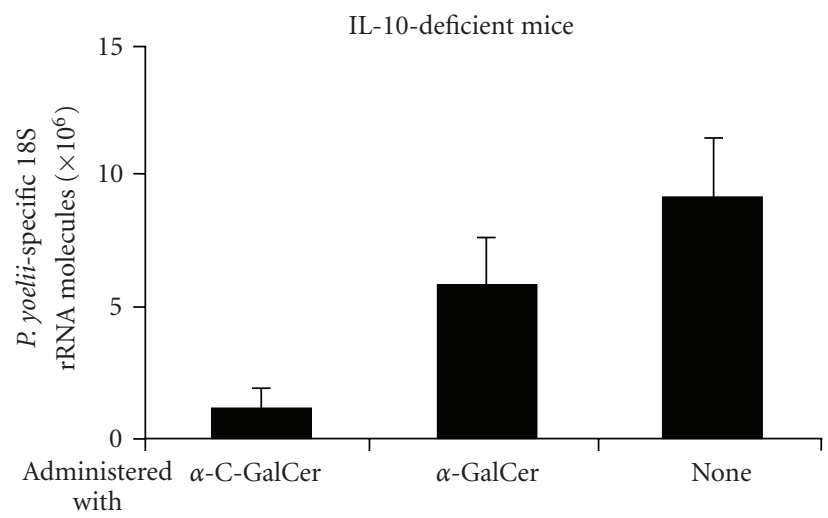

(d)

FIGURE 3: $\alpha$-C-GalCer's superior antimalarial activity does not involve IL-4 or IL-10. (a) Groups of 5 WT or IL-4-deficient BALB/c mice, or (b) groups of 5 WT or IL-10-deficient C57BL/6 mice, were treated i.p. with $1 \mu \mathrm{g}$ of either $\alpha$-C-GalCer or $\alpha$-GalCer or with nothing 3 days before challenge with live P. yoelii sporozoites, and then checked for malaria liver stage development. The results are expressed as the average $+/-\mathrm{SD}$ of 5 mice. The data shown come from one of three experiments with similar results.

curious to see if $\alpha$-C-GalCer's enhanced therapeutic activity against diseases ameliorated by Th1 cytokines stems from its ability to stimulate lower amounts of IL-4. To address this issue, we injected both WT mice and mice deficient in IL- 4 with equal doses of $\alpha$-GalCer or $\alpha$-C-GalCer, or with nothing, and 3 days later challenged them with live $P$. yoelii sporozoites. Forty-two hours after the challenge, we obtained livers from all the mice and determined the degree of malaria liver stages that developed by way of quantitative real-time RT-PCR. We found that the ability of $\alpha$-C-GalCer to better inhibit liver stages was the same in both IL-4-deficient mice and WT mice (Figure 3(a)). This result indicates that $\alpha$-CGalCer's superior antimalarial activity does not involve its reduced IL-4 production.

Another Th2 cytokine known to be produced following $\alpha$-GalCer injection in mice is IL-10 $[14,15]$. One of the important effects of IL-10 is the direct inhibition of IL-12 production by APCs, and the consequent downregulation of Th1-type responses [13, 16, 17]. Given IL-10's production consequent to glycolipid injection in mice, and its inhibitory affect on Th1-type responses, we wanted to see if IL-10 plays a role in $\alpha$-C-GalCer's enhanced therapeutic activity against diseases ameliorated by Th1 cytokines. To address this issue, we injected IL-10-deficient mice and WT mice with equal doses of $\alpha$-GalCer or $\alpha$-C-GalCer, or with nothing, and 3 days later challenged them with live sporozoites for a liver stage protection experiment. As with IL-4 deficient mice, we found that IL-10-deficient mice injected with $\alpha$-C-GalCer inhibited malarial liver stages better than those injected with $\alpha$-GalCer-the same as WT mice (Figure 3(b)). Thus, it appears that IL-10 also plays no role in $\alpha$-C-GalCer's enhanced antimalarial activity relative to $\alpha$-GalCer.

3.4. $\alpha$-C-GalCer Induces a Prolonged In Vivo Maturation of DCs Compared to $\alpha$-GalCer. In a previous study, we showed that CD8 $\alpha+$ DCs are the cells responsible for producing IL12 in response to $\alpha$-GalCer and $\alpha$-C-GalCer injection, and that depletion of these cells results in attenuated downstream IFN- $\gamma$ production by NK cells [7]. Given the importance of DCs in the in vivo physiological response to $\alpha$-GalCer and $\alpha$-C-GalCer, we wanted to see how these two glycolipids affect these cells in vivo in WT mice. To address this issue we looked at the ability of $\alpha$-GalCer and $\alpha$-C-GalCer to induce maturation of DCs by following the expression patterns of 


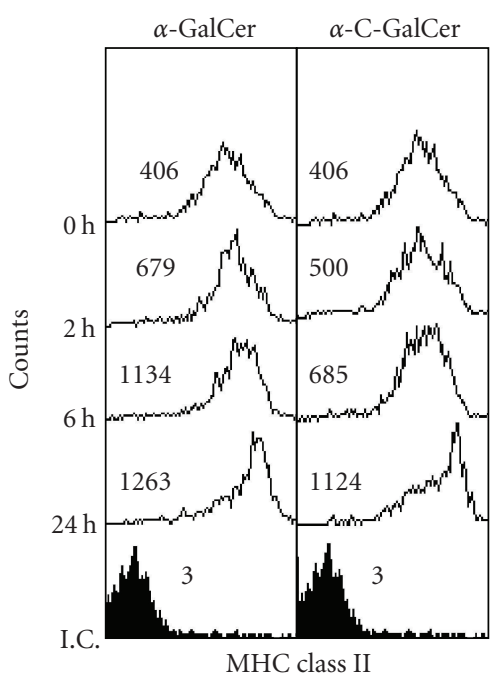

(a)

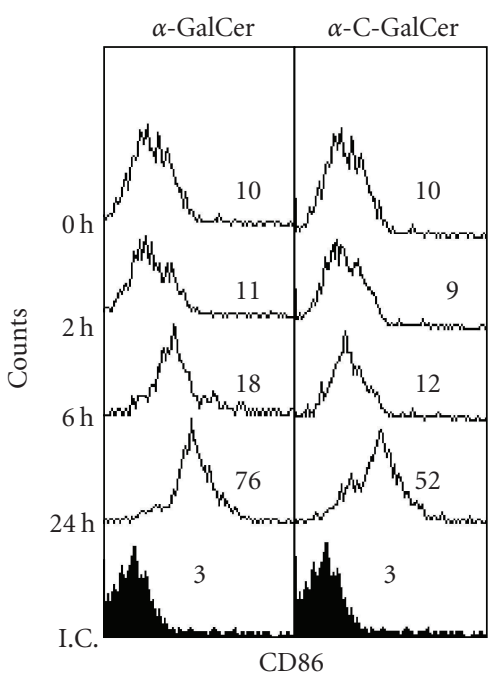

(b)

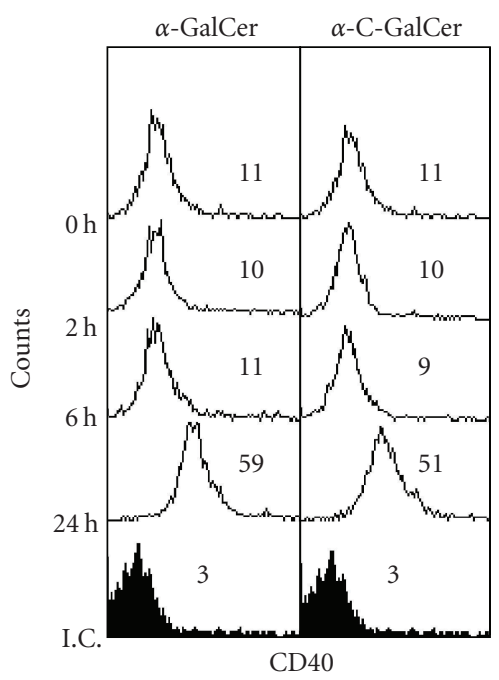

(c)

Figure 4: $\alpha$-C-GalCer induces a prolonged in vivo maturation of DCs compared to $\alpha$-GalCer. Groups of 3 WT mice were injected i.p. with $1 \mu \mathrm{g} \alpha$-GalCer or $\alpha$-C-GalCer, or with nothing, and 2, 6, or 24 hours later splenocytes were collected and subjected to FACS analysis. CD11c+ cells were gated and analyzed for their levels of (a) MHC class II, (b) CD86, and (c) CD40 at the different time points after glycolipid administration. Also shown are isotype control stainings obtained from the maximally activated, 24-hour, $\alpha$-GalCer-treated splenocyte populations, gated on CD11c+ cells. The numbers next to each histogram tracing represent the mean fluorescence intensity for that tracing. The data shown come from one of four experiments with similar results.

various surface markers known to be upregulated during DC maturation, namely, MHC class II, CD86, and CD40. More specifically, we injected WT mice with $\alpha$-GalCer, $\alpha$-C-GalCer, or nothing, and 2, 6, and 24 hours later obtained splenocytes for FACS analysis of cells coexpressing CD11c and MHC class II, CD86, or CD40.

We found that the first marker to show upregulation on CD11c+ DCs after injection of either glycolipid was MHC class II. $\alpha$-GalCer-treated mice showed increased expression of this marker as soon as 2 hours after injection, while $\alpha$ C-GalCer-treated mice showed increased expression 6 hours after injection (Figure 4(a)). By 24 hours posttreatment, we saw the highest MHC class II expression on CD11c+ DCs from mice injected with either $\alpha$-GalCer or $\alpha$-C-GalCer, with $\alpha$-GalCer-treated mice expressing slightly more marker than $\alpha$-C-GalCer-treated mice (Figure 4(a)).

The next marker to show upregulation after glycolipid injection was CD86. In $\alpha$-GalCer-treated mice, CD86 expression first started showing an increase at 6 hours postinjection; whereas in $\alpha$-C-GalCer-treated mice this marker did not show increased expression until 24 hours postinjection (Figure 4(b)). Again, as with MHC class II, we observed the highest expression of CD86 24 hours after injection of $\alpha$-GalCer or $\alpha$-C-GalCer, with $\alpha$-GalCer-treated mice expressing more marker than $\alpha$-C-GalCer-treated mice at this time point (Figure 4(b)).

Finally, the last DC marker to show upregulation following glycolipid injection was CD40. In both $\alpha$-GalCer- and $\alpha$ C-GalCer-injected mice, increased expression of this marker was only observed 24 hours after treatment. At 2 and 6 hours postglycolipid injection, CD40 expression on DCs was the same as untreated controls (Figure 4(c)). Interestingly, at 24 hours postinjection the expression levels of CD40 on DCs from both $\alpha$-GalCer- and $\alpha$-C-GalCer-treated mice were more or less the same, in contrast to MHC class II and CD86 (Figure 4(c)). Overall, the upregulation data indicates that $\alpha$-GalCer induces a faster maturation of CD11c+ DCs than does $\alpha$-C-GalCer, which appears to induce a more prolonged maturation of this cell type.

3.5. $\alpha$-C-GalCer Induces a Slower and Shorter In Vivo Downregulation of Va14i TCRs and a Greater In Vivo Proliferation of Va14i NKT Cells Compared to $\alpha$-GalCer. A number of recent studies have shown that $\mathrm{V} \alpha 14 \mathrm{i}$ NKT cells proliferate in vivo following injection of $\alpha$-GalCer [18-21]. This proliferation is accompanied by early downregulation of V $\alpha 14 \mathrm{i}$ TCRs and NK1.1 on the surface of NKT cells, followed by reappearance of these markers two days later. A finding from earlier studies that $\alpha$-C-GalCer stimulates less cytokine production by NKT cells than $\alpha$-GalCer $[6,8]$ suggests that $\alpha$-C-GalCer is a weaker NKT cell stimulus than $\alpha$-GalCer. To see if $\alpha$-CGalCer also stimulates poorer proliferation of NKT cells when compared to $\alpha$-GalCer, we injected WT mice with equal doses of either glycolipid, and 5, 24, 48, 72, 120, and 168 hours later obtained splenocytes and liver lymphocytes for FACS analysis of V $\alpha 14$ i NKT cells. To detect V $\alpha 14$ i NKT cells we made use of recently developed mouse CD1d-IgG1 dimers, which, when loaded with $\alpha$-GalCer, stain V $\alpha 14$ i NKT cells [22].

We found that V $\alpha 14$ i NKT cells from $\alpha$-GalCer-treated mice rapidly downregulated their TCRs, becoming undetectable in both spleen and liver by 5 hours, and remaining so at 24 hours (Figure 5(a)). Not until 48 hours did V $\alpha 14$ i NKT cells from $\alpha$-GalCer-treated mice become detectable again in 


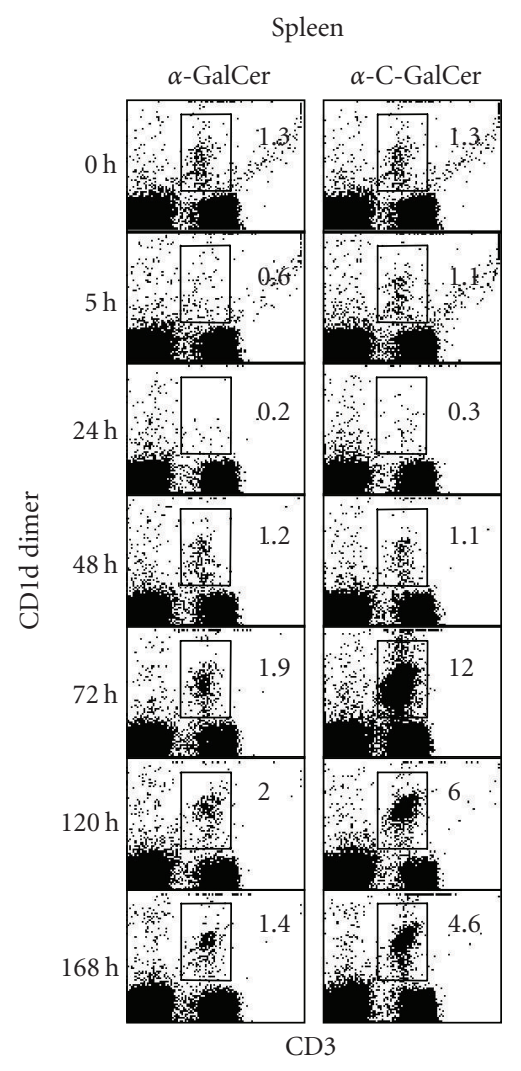

(a)

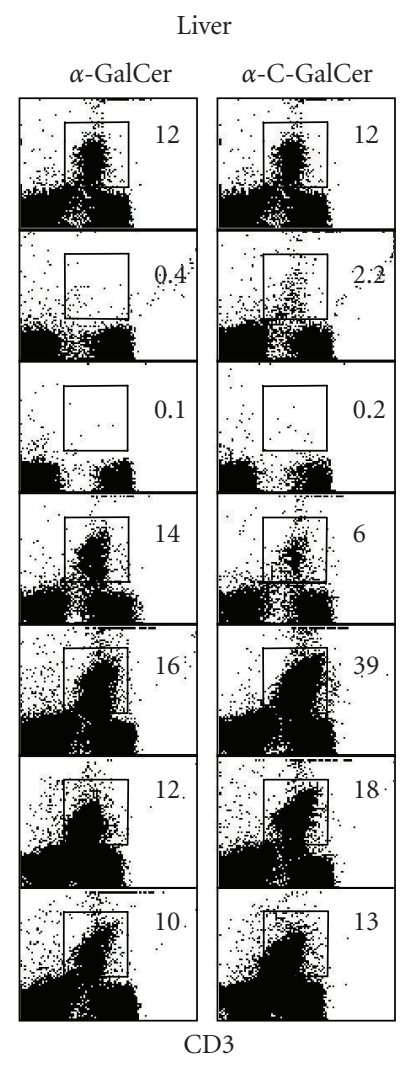

CD3
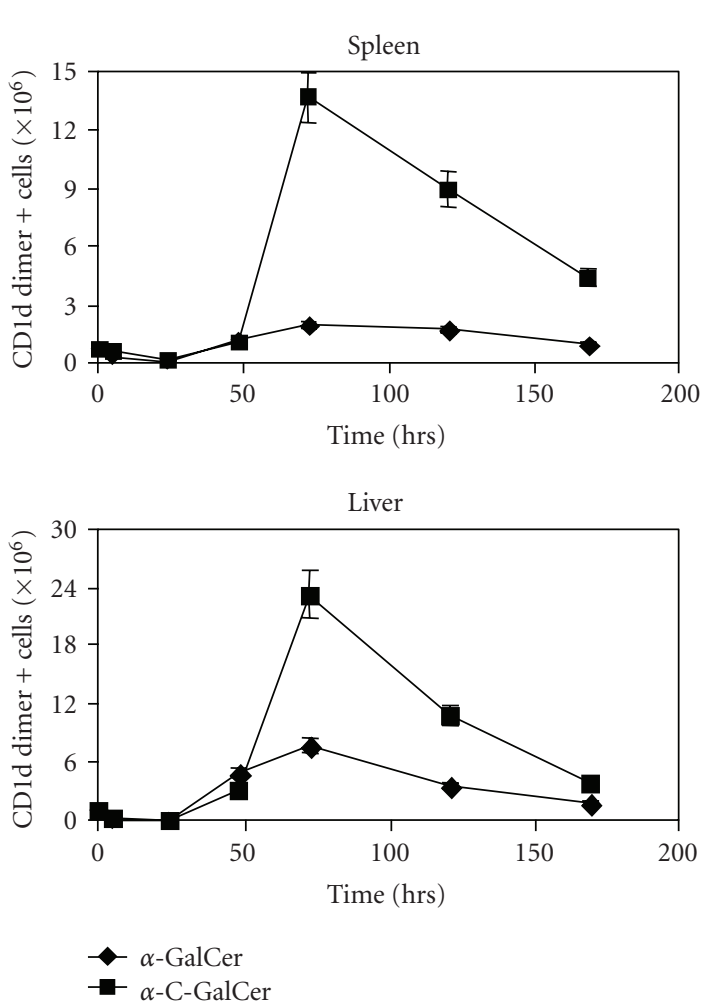

(b)

FIGURE 5: $\alpha$-C-GalCer induces a slower and shorter in vivo downregulation of V $\alpha 14 \mathrm{i}$ TCRs and a greater in vivo proliferation of V $\alpha 14 \mathrm{i}$ NKT cells compared to $\alpha$-GalCer. (a) Groups of 2 WT C57BL/6 mice were injected i.p. with $1 \mu \mathrm{g}$ of $\alpha$-GalCer or $\alpha$-C-GalCer, and 0, 5, 24, 48, 72, 120, and 168 hours later splenocytes and liver lymphocytes were isolated and stained with $\alpha$-GalCer-loaded mouse CD1d-IgG dimers to assess the level of $\mathrm{V} \alpha 14 \mathrm{i}$ NKT cells present. The numbers shown in the individual panels represent the percentage of V $\alpha 14 \mathrm{i}$ NKT cells present in the gated lymphocyte population. The data shown are representative of three independent experiments. (b) The average absolute numbers of V $\alpha 14 \mathrm{i}$ NKT cells in the spleens and livers of $\alpha$-GalCer- and $\alpha$-C-GalCer-treated mice at the various time points were calculated according to the following equation: (percentage of $\mathrm{V} \alpha 14 \mathrm{i}$ NKT cells in the gated lymphocyte population) $*$ (percentage of total isolated cells represented by the gated lymphocyte population) $*$ (total number of isolated cells). The data shown are the average values calculated from three independent experiments $+/-\mathrm{SE}$.

both spleen and liver. At this time point the cells returned to levels comparable to that detected prior to injection, and remained so at 72,120 , and 168 hours postinjection (Figure 5(a)).

In contrast to $\alpha$-GalCer, V $\alpha 14$ i NKT cells from mice treated with $\alpha$-C-GalCer exhibited a slower and shorter TCR downregulation, with small percentages of cells still present at 5 hours in both spleen and liver (Figure 5(a)). At 24 hours the cells were almost completely undetectable, but started reappearing at 48 hours, although at lower levels than that detected prior to injection (Figure 5(a)). Strikingly, at 72 hours the levels of $\mathrm{V} \alpha 14 \mathrm{i}$ NKT cells in the spleens and livers of $\alpha$-C-GalCer-treated mice were greatly increased over that observed prior to injection. In the spleen, the percentage of cells was approximately 10 times higher than that observed at the start; similarly, in the liver the percentage was about 3 times higher (Figure 5(a)). At 120 hours, the levels of V $\alpha 14 \mathrm{i}$ NKT cells started to come down in both the spleen and liver, but still remained higher than that observed prior to injection. By 168 hours, the percentages continued to come down, approaching baseline in the liver, but remaining high in the spleen (Figure 5(a)).

Using the percentages of V $\alpha 14 \mathrm{i}$ NKT cells we were able to follow the overall proliferative response of the cells stimulated by the glycolipids. We found that the overall pattern of V $\alpha 14$ i NKT cell expansion was the same for both glycolipids, with peak cell numbers occurring 72 hours postinjection followed by a return towards baseline (Figure 5(b)). Surprisingly, we found that $\alpha$-C-GalCer stimulated a far greater expansion of V $\alpha 14$ i NKT cells in both spleen and liver than did $\alpha$-GalCer. The difference was most striking at 72 hours when the numbers of V $\alpha 14$ i NKT cells in the spleens and livers of $\alpha$-C-GalCer-treated mice were approximately 5 times higher than those in $\alpha$-GalCer-treated mice (Figure 5(b)). Overall, this data indicates that despite its poor ability to stimulate cytokine production by NKT cells [6], $\alpha$-C-GalCer is a better in vivo stimulus for V $\alpha 14 \mathrm{i}$ NKT cell proliferation than $\alpha$-GalCer. 


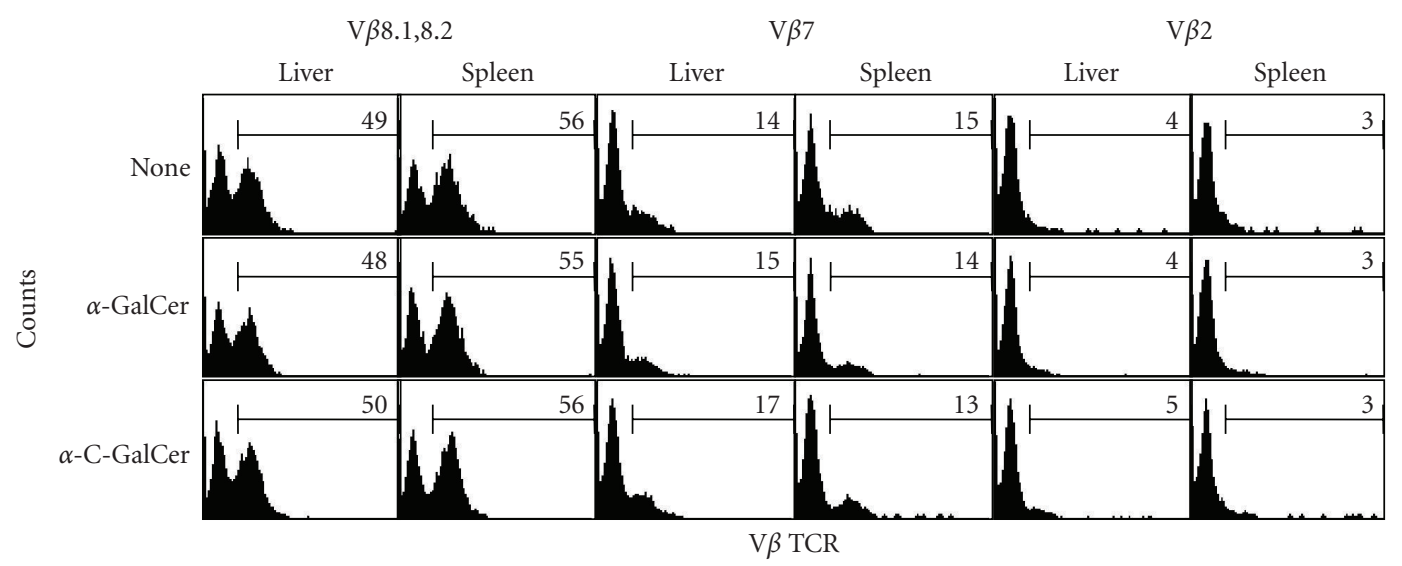

FIGURE 6: TCR $\beta$ usage does not affect in vivo V $\alpha 14 \mathrm{i}$ NKT cell activation stimulated by $\alpha$-GalCer or $\alpha$-C-GalCer. Groups of 2 WT C57BL/6 were injected i.p. with $1 \mu \mathrm{g}$ of $\alpha$-GalCer or $\alpha$-C-GalCer, or with nothing, and 72 hours later splenocytes and hepatic lymphocytes were isolated and stained for $\mathrm{V} \alpha 14 \mathrm{i}$ NKT cells using $\alpha$-GalCer-loaded mouse CD1d-IgG dimers, as well as for V $\beta 8.1 / 8.2, \mathrm{~V} \beta 7$, and $\mathrm{V} \beta 2$. V $\alpha 14 \mathrm{i}$ NKT cells were gated, and FACS analyzed for the three different V $\beta$ gene segments. The numbers shown represent the percentage of cells expressing the indicated $\mathrm{V} \beta$ segment. The data shown comes from one of two independent experiments with similar results.

3.6. TCR $\beta$ Usage Does Not Affect In Vivo Va14i NKT Cell Activation Stimulated by $\alpha$-GalCer or $\alpha$-C-GalCer. Two recent studies show that TCR $\beta$ usage by V $\alpha 14$ i NKT cells affects the avidity of V $\alpha 14 \mathrm{i}$ TCRs for CD1d-glycolipid complexes $[22,23]$. In particular, they indicate that TCR $\beta$ chains encoded by the V $\beta 8.2$ gene segment confer higher avidity to $\mathrm{V} \alpha 14 \mathrm{i}$ TCRs than $\mathrm{V} \beta 7$ or $\mathrm{V} \beta 2$, and that glycolipid ligands preferentially stimulate these higher avidity cells. Despite these findings, our data showing a complete disappearance of V $\alpha 14 \mathrm{i}$ NKT cells by 24 hours post- $\alpha$ GalCer or $\alpha$-C-GalCer injection (Figure 5(a)) suggests that in vivo both glycolipids stimulate all V $\alpha 14 \mathrm{i}$ NKT cells regardless of their TCR $\beta$ usage. To confirm this suspicion, we treated WT mice with $\alpha$-GalCer, $\alpha$-C-GalCer, or with nothing, and 72 hours later obtained splenocytes and liver lymphocytes for staining with CD1d-IgG1 dimer loaded with $\alpha$-GalCer. In addition to dimer staining, we also stained the cells for $\mathrm{V} \beta 8.1 / 8.2, \mathrm{~V} \beta 7$, and $\mathrm{V} \beta 2$ to see if the distribution V $\alpha 14$ i NKT cells changes after glycolipid-mediated stimulation. More specifically, if $\alpha$-GalCer or $\alpha$-C-GalCer preferentially stimulates the higher avidity $\mathrm{V} \beta 8$.2-containing NKT cells in vivo, then there should be an increase in the proportions of these cells in the expanded NKT cell population that results after glycolipid-induced proliferation. We found that there was no difference in the proportions of TCR $\beta$ usage by V $\alpha 14$ i NKT cells before or after stimulation with $\alpha$-GalCer or $\alpha$-C-GalCer (Figure 6). Prior to glycolipid administration about $50 \%$ of $\mathrm{V} \alpha 14 \mathrm{i}$ NKT cells in the livers and spleens of mice expressed $\mathrm{V} \beta 8.1 / 8.2$, while about $15 \%$ expressed $\mathrm{V} \beta 7$ and $3-4 \%$ expressed $\mathrm{V} \beta 2$. These proportions did not change after $\alpha$ GalCer- or $\alpha$-C-GalCer-induced proliferation (Figure 6). In all, these results suggest that TCR $\beta$ usage does not affect in vivo $\mathrm{V} \alpha 14 \mathrm{i}$ NKT cell activation stimulated by $\alpha$-GalCer or $\alpha$-C-GalCer.

\section{Discussion}

The current study further defines the physiologic mechanism by which $\alpha$-C-GalCer exhibits its superior antimalarial activity when compared to its structurally similar analog $\alpha$ - GalCer. As reported previously $\alpha$-C-GalCer's enhanced antimalarial effect appears to stem from prolonged downstream IFN- $\gamma$ production by NK cells requiring IL-12 [6]. This requirement for IL-12 is reconfirmed in the present study by our results showing the abrogation of $\alpha$-C-GalCer's enhanced therapeutic effect against malaria liver stages in mice lacking IL-12 (Figure 2(a)). The current study also definitively defines the important role of NK cells in the mechanism of $\alpha$-C-GalCer's enhanced antimalarial effect. Our finding that NK cell depletion abrogates $\alpha$-C-GalCer's superior antimalarial activity when compared to $\alpha$-GalCer attests to the key role these cells play (Figure 2(b)). In addition, despite a previously reported finding that $\alpha$-CGalCer stimulates less IL- 4 than $\alpha$-GalCer $[6,8]$, the ability of $\alpha$-C-GalCer to stimulate diminished production of Th2 cytokines like IL-4 and IL-10 has no affect on its superior therapeutic activity relative to $\alpha$-GalCer (Figure 3 ). Taken together, these data, along with our prior results showing that $\mathrm{CD} 8 \alpha+$ DCs are the cells responsible for producing IL12 in response to glycolipid injection [7], indicate that $\alpha$-CGalCer's superior antimalarial activity stems from its ability to stimulate prolonged IL-12 production by DCs thereby resulting in enhanced downstream IFN- $\gamma$ production by NK cells, and enhanced protection (Figure 7).

Our previous finding that $\alpha$-C-GalCer stimulates prolonged IL-12 by DCs [7] correlates with our current finding that $\alpha$-C-GalCer induces prolonged maturation of DCs after injection into mice (Figure 4). The fact that DCs mature at a slower rate after $\alpha$-C-GalCer administration than after $\alpha$ GalCer administration implies that the NKT cell inputs into 


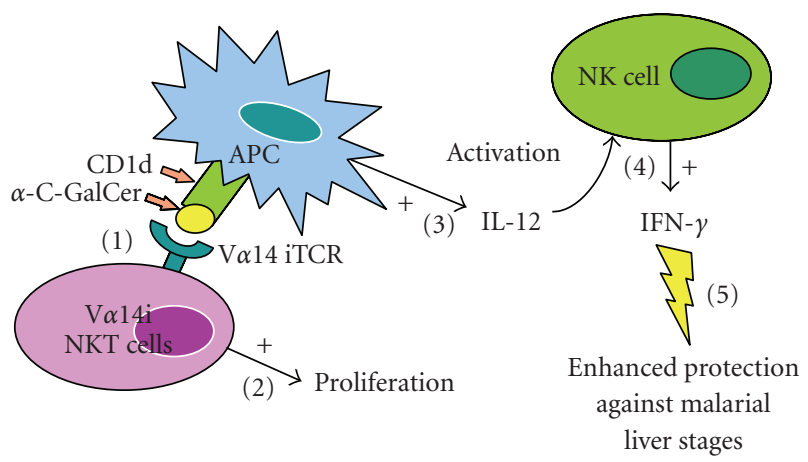

FIgure 7: Mechanism of $\alpha$-C-GalCer's enhanced therapeutic effect against malarial liver stages: (1) $\alpha$-C-GalCer presented by CD1d molecules expressed on APCs stimulates, (2) enhanced (+) proliferation by V $\alpha 14$ i NKT cells relative to $\alpha$-GalCer, and (3) enhanced $(+)$ activation and IL-12 release by APCs compared to $\alpha$-GalCer, which (4) induces augmented IFN- $\gamma$ production by NK cells. This increased IFN- $\gamma$ is responsible for (5) the better protection against malarial liver stages exhibited by $\alpha-\mathrm{C}-\mathrm{GalCer}$.

$\alpha$-C-GalCer-bearing DCs are weaker than those delivered to $\alpha$-GalCer-bearing DCs. These weaker inputs might stem from a lower affinity interaction between the V $\alpha 14 \mathrm{i}$ TCR and the CD1d- $\alpha$-C-GalCer complex. In light of studies demonstrating NKT cell TCR downregulation hours after encounter with $\alpha$-GalCer-bearing APCs [19-21], as well as other studies showing that high affinity interactions result in faster and greater TCR downregulation [24, 25], the weaker V $\alpha 14 \mathrm{i}$ TCR:CD1d- $\alpha$-C-GalCer interaction would be expected to result in slower and lesser downregulation of V $\alpha 14 \mathrm{i}$ TCRs on NKT cells than that seen with $\alpha$-GalCer. Indeed, our experiment looking at the disappearance and reappearance of $\mathrm{V} \alpha 14 \mathrm{i} \mathrm{NKT}$ cells after $\alpha$-GalCer or $\alpha$ C-GalCer administration demonstrated precisely this phenomenon (Figure 5). As a consequence of shorter/lesser TCR downregulation, longer contact between NKT cells and $\alpha$ C-GalCer-bearing DCs probably occurs, which would result in a temporal summation of NKT cell inputs by DCs that might exceed that achieved by $\alpha$-GalCer-bearing DCs, which receive stronger- but shorter-lived inputs from NKT cells due to the higher affinity interaction between the V $\alpha 14 \mathrm{i}$ TCR and the CD1d- $\alpha$-GalCer complex. Since glycolipid-induced IL12 production by DCs requires contact with NKT cells [2631], $\alpha$-C-GalCer's ability to stimulate prolonged IL-12 might stem from longer contact time between NKT cells and $\alpha-\mathrm{C}$ GalCer-bearing DCs.

In addition to stimulating a slower and shorter downregulation of TCRs on V $\alpha 14 \mathrm{i}$ NKT cells, the interaction between CD1d- $\alpha$-C-GalCer complexes and V $\alpha 14 \mathrm{i}$ TCRs also stimulates a greater in vivo expansion of $\mathrm{V} \alpha 14 \mathrm{i}$ NKT cells compared to $\alpha$-GalCer (Figure 5). This result is surprising because earlier data from us and others demonstrating that $\alpha$-C-GalCer stimulates less cytokine production by NKT cells than $\alpha$-GalCer $[6,8]$ implies that $\alpha$-C-GalCer is a weaker agonist for NKT cells. It is likely that the striking differences we observed in the abilities of $\alpha$-GalCer and $\alpha$-C-GalCer to induce cytokine synthesis and cellular expansion by NKT cells are the result of differential TCR signal transduction events, which probably stem from the difference in affinities between the V $\alpha 14$ i TCR:CD1d- $\alpha$-GalCer interaction and the V $\alpha 14$ i TCR:CD1d- $\alpha$-C-GalCer interaction.

This situation is analogous to a previous study showing that a partial $\mathrm{T}$ cell agonist incapable of stimulating early $\mathrm{T}$ cell activation events was capable of stimulating later events, such as proliferation, to the same degree or better as the full agonist [32]. These findings were explained by the so-called kinetic proofreading model for $\mathrm{T}$ cell activation, which proposes that while early $\mathrm{T}$ cell activation events depend on the affinity of TCR:MHC-peptide interactions, later $\mathrm{T}$ cell activation events depend more on the temporal summation of successive TCR signals delivered by MHCpeptide complexes serially engaging different TCRs over time $[24,32-36]$. Based on this model, it is possible that $\alpha$ C-GalCer is a partial NKT cell agonist, whose ability to stimulate enhanced $\mathrm{V} \alpha 14 \mathrm{i}$ NKT cell expansion is due to enhanced temporal summation of APC inputs by NKT cells made possible by slower and shorter TCR downregulation and prolonged contact between NKT cells and $\alpha$-C-GalCerbearing APCs. While more research is needed to verify this mechanism, it is interesting to note that TCR $\beta$ usage does not appear to effect $\alpha$-C-GalCer's stimulation of NKT cells (Figure 6) despite two recent studies showing that TCR $\beta$ chains encoded by the V $\beta 8.2$ gene segment confer higher avidity to $\mathrm{V} \alpha 14 \mathrm{i}$ TCRs than $\mathrm{V} \beta 7$ or $\mathrm{V} \beta 2$, and that glycolipid ligands preferentially stimulate these higher avidity cells [22, 23].

\section{Conclusions}

We have previously shown that the C-glycoside analog of $\alpha$ GalCer, $\alpha$-C-GalCer, displays a superior inhibitory activity against the liver stages of the rodent malaria parasite $P$. yoelii. In the present study, we not only confirmed that IL-12 is a key factor that mediates the antiplasmodial activity of both glycolipids, but also defined the important role of NK cells as mediators of $\alpha$-C-GalCer's superior effect. We found that the Th 2 cytokines IL- 4 and IL-10 are not involved. Moreover, we demonstrated a differential activity of $\alpha$-C-GalCer in its stimulation of DCs as compared to $\alpha$-GalCer, and correlated this with an enhanced proliferative response of $\mathrm{V} \alpha 14 \mathrm{i} \mathrm{NKT}$ cells to $\alpha$-C-GalCer. Finally, we showed that V $\beta$ usage does not influence the response of $\mathrm{V} \alpha 14 \mathrm{i}$ NKT cells to either glycolipid.

\section{Acknowledgments}

The authors thank C. Palavacino for technical assistance and G. Eberl for critical review of the paper. They also thank Kirin Brewery Co. for providing $\alpha$-GalCer. This work was supported by the National Institutes of Health Grants GM60271 (to the third author) and AI-47840 (to the forth author) and a grant from NIH RCMI-RR-07037 supporting the infrastructure of the Department of Chemistry at Hunter College of the City University of New York. The forth author also was supported by New York University School of Medicine and the Irene Diamond Foundation. 


\section{References}

[1] V. Nussenzweig and R. S. Nussenzweig, "Rationale for the development of an engineered sporozoite malaria vaccine," Advances in Immunology, vol. 45, pp. 283-334, 1989.

[2] J. Schmieg, G. Gonzalez-Aseguinolaza, and M. Tsuji, "The role of natural killer $\mathrm{T}$ cells and other $\mathrm{T}$ cell subsets against infection by the pre-erythrocytic stages of malaria parasites," Microbes and Infection, vol. 5, no. 6, pp. 499-506, 2003.

[3] M. Kronenberg, "Toward an understanding of NKT cell biology: progress and paradoxes," Annual Review of Immunology, vol. 23, pp. 877-900, 2005.

[4] M. Tsuji, "Glycolipids and phospholipids as natural CD1dbinding NKT cell ligands," Cellular and Molecular Life Sciences, vol. 63, no. 16, pp. 1889-1898, 2006.

[5] G. Gonzalez-Aseguinolaza, C. de Oliveira, M. Tomaska, et al., " $\alpha$-galactosylceramide-activated $\mathrm{V} \alpha 14$ natural killer T cells mediate protection against murine malaria," Proceedings of the National Academy of Sciences of the United States of America, vol. 97, no. 15, pp. 8461-8466, 2000.

[6] J. Schmieg, G. Yang, R. W. Franck, and M. Tsuji, "Superior protection against malaria and melanoma metastases by a C-glycoside analogue of the natural killer T cell ligand $\alpha$ galactosylceramide," Journal of Experimental Medicine, vol. 198, no. 11, pp. 1631-1641, 2003.

[7] J. Schmieg, G. Yang, R. W. Franck, N. van Rooijen, and M. Tsuji, "Glycolipid presentation to natural killer T cells differs in an organ-dependent fashion," Proceedings of the National Academy of Sciences of the United States of America, vol. 102, no. 4, pp. 1127-1132, 2005.

[8] S.-I. Fujii, K. Shimizu, H. Hemmi, et al., "Glycolipid $\alpha$ C-galactosylceramide is a distinct inducer of dendritic cell function during innate and adaptive immune responses of mice," Proceedings of the National Academy of Sciences of the United States of America, vol. 103, no. 30, pp. 11252-11257, 2006.

[9] G. Yang, J. Schmieg, M. Tsuji, and R. W. Franck, "The C-glycoside analogue of the immunostimulant $\alpha$ galactosylceramide (KRN7000): synthesis and striking enhancement of activity," Angewandte Chemie International Edition, vol. 43, no. 29, pp. 3818-3822, 2004.

[10] O. Brua-Romero, J. C. R. Hafalla, G. Gonzalez-Aseguinolaza, G.-I. Sano, M. Tsuji, and F. Zavala, "Detection of malaria liver-stages in mice infected through the bite of a single Anopheles mosquito using a highly sensitive real-time PCR," International Journal for Parasitology, vol. 31, no. 13, pp. 1499$1502,2001$.

[11] P. Chomczynski and N. Sacchi, "Single-step method of RNA isolation by acid guanidinium thiocyanate-phenolchloroform extraction," Analytical Biochemistry, vol. 162, no. 1, pp. 156-159, 1987.

[12] M. J. Smyth, N. Y. Crowe, and D. I. Godfrey, "NK cells and NKT cells collaborate in host protection from methylcholanthrene-induced fibrosarcoma," International Immunology, vol. 13, no. 4, pp. 459-463, 2001.

[13] A. O'Garra and N. Arai, "The molecular basis of T helper 1 and T helper 2 cell differentiation," Trends in Cell Biology, vol. 10, no. 12, pp. 542-550, 2000.

[14] S. Sharif, G. A. Arreaza, P. Zucker, et al., "Activation of natural killer T cells by $\alpha$-galactosylceramide treatment prevents the onset and recurrence of autoimmune type 1 diabetes," Nature Medicine, vol. 7, no. 9, pp. 1057-1062, 2001.

[15] A. K. Singh, M. T. Wilson, S. Hong, et al., "Natural killer T cell activation protects mice against experimental autoimmune encephalomyelitis," Journal of Experimental Medicine, vol. 194, no. 12 , pp. 1801-1811, 2001.

[16] A. D'Andrea, M. Aste-Amezaga, N. M. Valiante, X. Ma, M. Kubin, and G. Trinchieri, "Interleukin 10 (IL-10) inhibits human lymphocyte interferon $\gamma$-production by suppressing natural killer cell stimulatory factor/IL-12 synthesis in accessory cells," Journal of Experimental Medicine, vol. 178, no. 3, pp. 1041-1048, 1993.

[17] M. Aste-Amezaga, X. Ma, A. Sartori, and G. Trinchieri, "Molecular mechanisms of the induction of IL-12 and its inhibition by IL-10," Journal of Immunology, vol. 160, no. 12, pp. 5936-5944, 1998.

[18] K.-I. Seino, M. Harada, and M. Taniguchi, "NKT cells are relatively resistant to apoptosis," Trends in Immunology, vol. 25, no. 5, pp. 219-221, 2004.

[19] M. T. Wilson, C. Johansson, D. Olivares-Villagomez, et al., "The response of natural killer T cells to glycolipid antigens is characterized by surface receptor down-modulation and expansion," Proceedings of the National Academy of Sciences of the United States of America, vol. 100, no. 19, pp. 10913-10918, 2003.

[20] N. Y. Crowe, A. P. Uldrich, K. Kyparissoudis, et al., "Glycolipid antigen drives rapid expansion and sustained cytokine production by NK T cells," Journal of Immunology, vol. 171, no. 8, pp. 4020-4027, 2003.

[21] M. Harada, K.-I. Seino, H. Wakao, et al., "Down-regulation of the invariant $\mathrm{V} \alpha 14$ antigen receptor in NKT cells upon activation," International Immunology, vol. 16, no. 2, pp. 241247, 2004.

[22] J. Schumann, R. B. Voyle, B.-Y. Wei, and H. R. MacDonald, "Cutting edge: influence of the TCR V $\beta$ domain on the avidity of CD1d: $\alpha$-galactosylceramide binding by invariant $\mathrm{V} \alpha 14$ NKT cells," Journal of Immunology, vol. 170, no. 12, pp. 58155819, 2003.

[23] A. K. Stanic, R. Shashidharamurthy, J. S. Bezbradica, et al., "Another view of $\mathrm{T}$ cell antigen recognition: cooperative engagement of glycolipid antigens by Va14Ja18 natural TCR," Journal of Immunology, vol. 171, no. 9, pp. 4539-4551, 2003.

[24] S. Valitutti, S. Muller, M. Cella, E. Padovan, and A. Lanzavecchia, "Serial triggering of many T-cell receptors by a few peptide-MHC complexes," Nature, vol. 375, no. 6527, pp. 148151, 1995.

[25] Z. Cai, H. Kishimoto, A. Brunmark, M. R. Jackson, P. A. Peterson, and J. Sprent, "Requirements for peptide-induced T cell receptor downregulation on naive CD8 ${ }^{+} \mathrm{T}$ cells," Journal of Experimental Medicine, vol. 185, no. 4, pp. 641-651, 1997.

[26] J. L. Matsuda, L. Gapin, J. L. Baron, et al., "Mouse V $\alpha 14$ i natural killer $\mathrm{T}$ cells are resistant to cytokine polarization in vivo," Proceedings of the National Academy of Sciences of the United States of America, vol. 100, no. 14, pp. 8395-8400, 2003.

[27] H. Kitamura, K. Iwakabe, T. Yahata, et al., "The natural killer $\mathrm{T}$ (NKT) cell ligand $\alpha$-galactosylceramide demonstrates its immunopotentiating effect by inducing interleukin (IL)-12 production by dendritic cells and IL-12 receptor expression on NKT cells," Journal of Experimental Medicine, vol. 189, no. 7, pp. 1121-1127, 1999.

[28] M. Tomura, W.-G. Yu, H.-J. Ahn, et al., "A novel function of $\mathrm{V} \alpha 14^{+} \mathrm{CD} 4^{+} \mathrm{NKT}$ cells: stimulation of IL-12 production by antigen-presenting cells in the innate immune system," Journal of Immunology, vol. 163, no. 1, pp. 93-101, 1999.

[29] Y.-F. Yang, M. Tomura, S. Ono, T. Hamaoka, and H. Fujiwara, "Requirement for IFN- $\gamma$ in IL-12 production induced by collaboration between $\mathrm{V} \alpha 14+$ NKT cells and antigen-presenting 
cells," International Immunology, vol. 12, no. 12, pp. 1669$1675,2000$.

[30] S.-I. Fujii, K. Shimizu, C. Smith, L. Bonifaz, and R. M. Steinman, "Activation of natural killer T cells by $\alpha$ galactosylceramide rapidly induces the full maturation of dendritic cells in vivo and thereby acts as an adjuvant for combined CD4 and CD8 T cell immunity to a coadministered protein," Journal of Experimental Medicine, vol. 198, no. 2, pp. 267-279, 2003.

[31] S.-I. Fujii, K. Liu, C. Smith, A. J. Bonito, and R. M. Steinman, "The linkage of innate to adaptive immunity via maturing dendritic cells in vivo requires CD40 ligation in addition to antigen presentation and CD80/86 costimulation," Journal of Experimental Medicine, vol. 199, no. 12, pp. 1607-1618, 2004.

[32] C. Rosette, G. Werlen, M. A. Daniels, et al., "The impact of duration versus extent of TCR occupancy on T cell activation: a revision of the kinetic proofreading model," Immunity, vol. 15 , no. 1, pp. 59-70, 2001.

[33] J. Sloan-Lancaster and P. M. Allen, "Altered peptide ligandinduced partial $\mathrm{T}$ cell activation: molecular mechanisms and role in T cell biology," Annual Review of Immunology, vol. 14, pp. 1-27, 1996.

[34] A. E. Nel and N. Slaughter, "T-cell activation through the antigen receptor. Part 2: role of signaling cascades in T-cell differentiation, anergy, immune senescence, and development of immunotherapy," Journal of Allergy and Clinical Immunology, vol. 109, no. 6, pp. 901-915, 2002.

[35] S. Valitutti and A. Lanzavecchia, "Serial triggering of TCRs: a basis for the sensitivity and specificity of antigen recognition," Immunology Today, vol. 18, no. 6, pp. 299-304, 1997.

[36] J. Rachmilewitz and A. Lanzavecchia, "A temporal and spatial summation model for T-cell activation: signal integration and antigen decoding," Trends in Immunology, vol. 23, no. 12, pp. 592-595, 2002. 

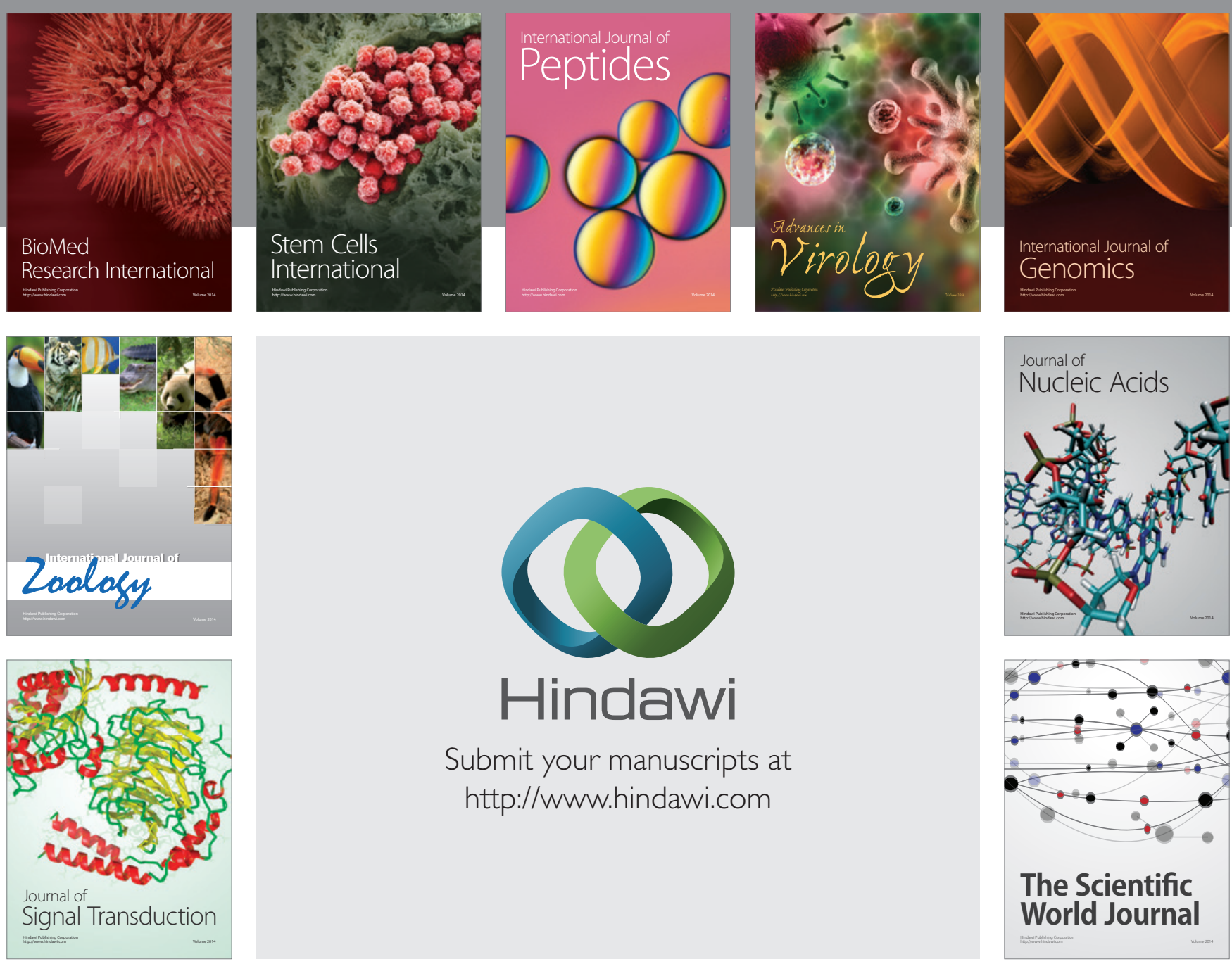

Submit your manuscripts at

http://www.hindawi.com
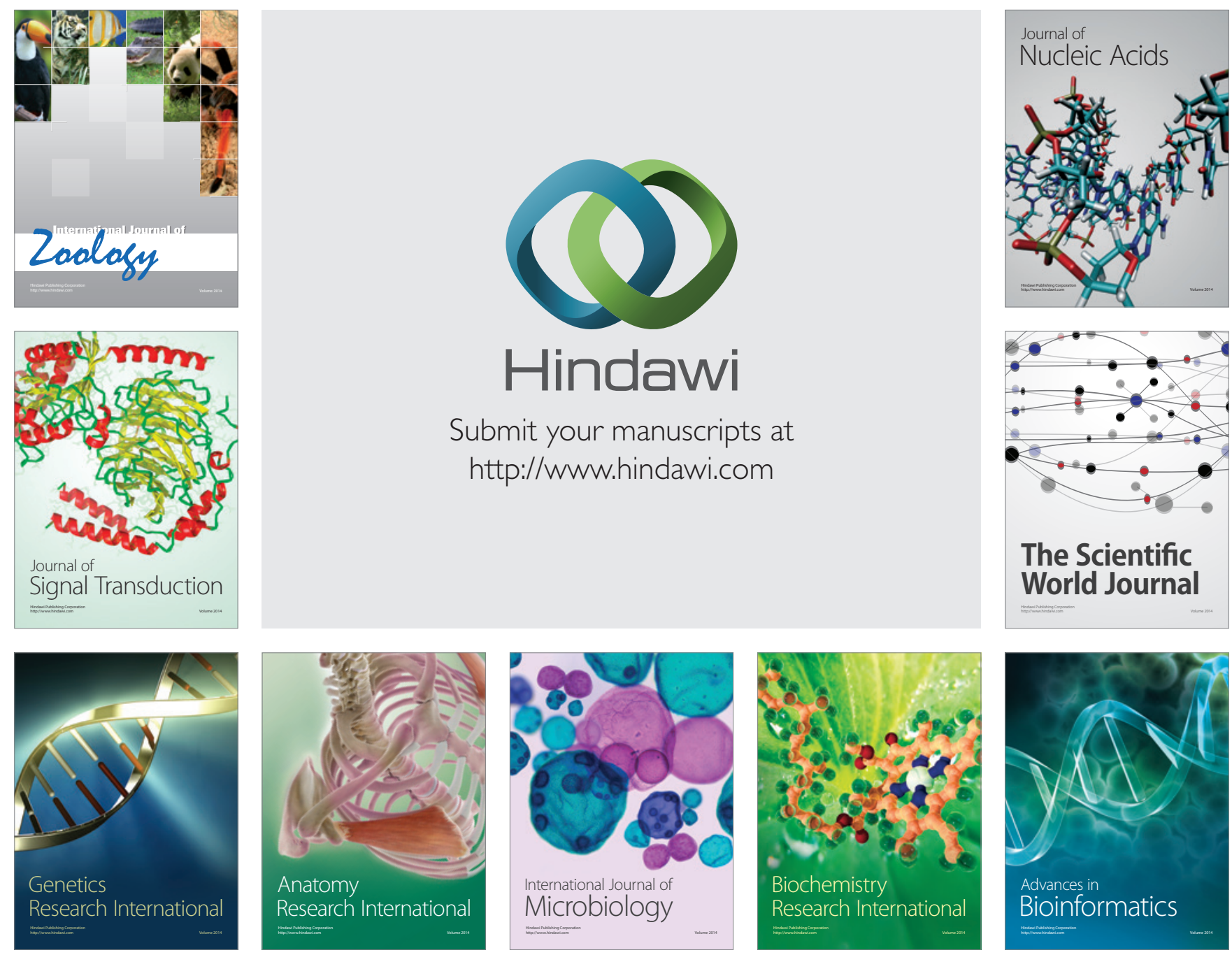

The Scientific World Journal
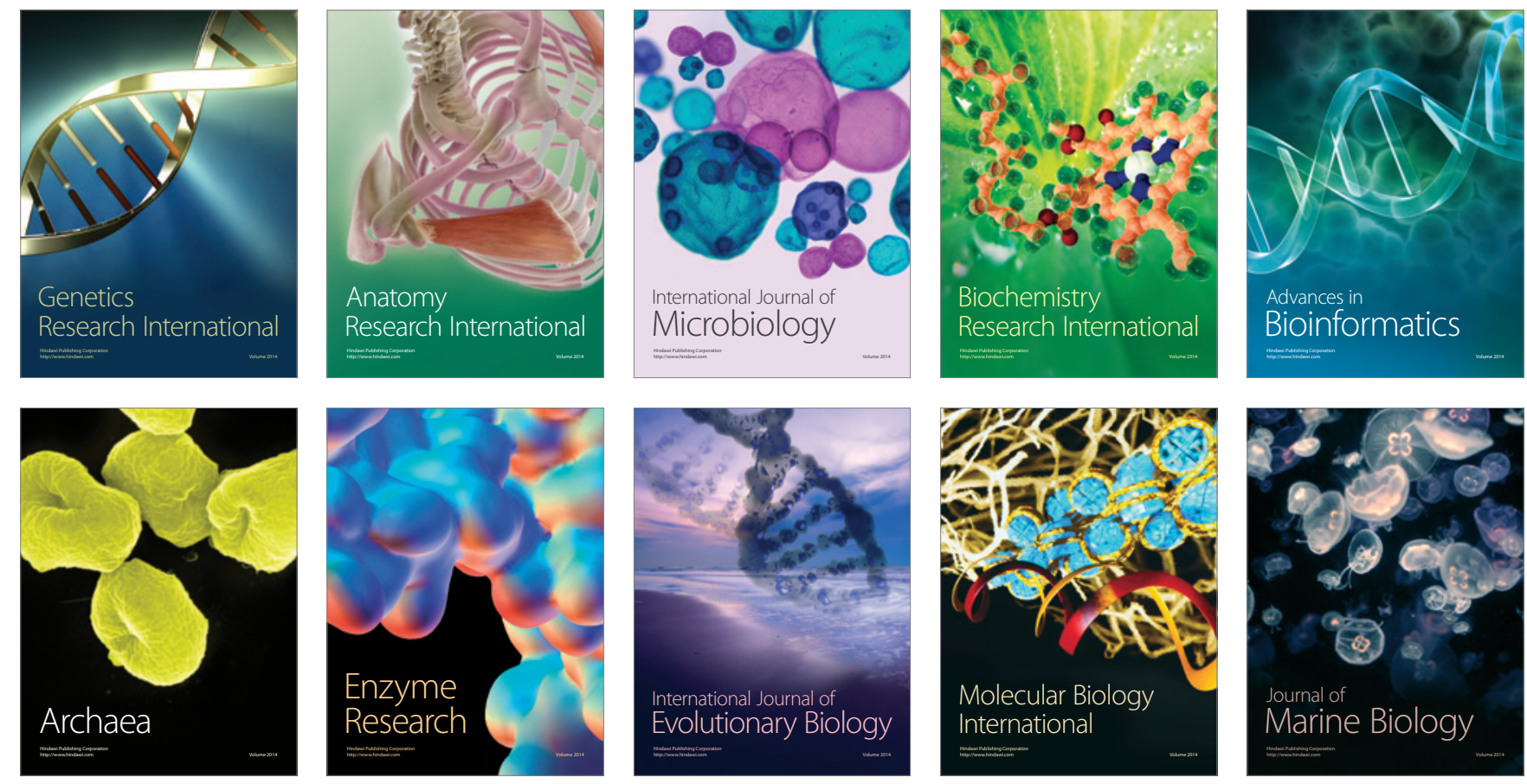